\title{
Pengaruh Waktu Fermentasi Teh Kombucha Kadar 50\% Terhadap Tebal Dinding Dan Diameter Lumen Arteria Koronaria Tikus Putih
}

\author{
Sri Isdadiyanto \\ Departemen Biologi, Fakultas Sains dan Matematika, Universitas Diponegoro \\ Jalan Prof. H. Soedarto, S.H., Tembalang, Semarang, \\ Email: : isdadiyanto@yahoo.com
}

\begin{abstract}
The objective of this study was to analyze the influences of 50\% kombucha tea level on wall thickness and lumen diameter of coronary artery in rats. Sixteen male Rattus norvegicus rats, 2 months of age were used as experimental animals, with treatment kombucha tea that has been fermented for 6,9 and 12 days at the temperature of $25^{\circ} \mathrm{C}$ per oral. The research design used to a completely randomized with 4 treatment (for 4 weeks) and 4 replications, i.e., $\mathrm{P} 0=$ control, without of kombucha tea, $\mathrm{P} 1=$ water $+1,8 \mathrm{ml}$ kombucha tea that has been fermented for 6 days in the morning and afternoon, $\mathrm{P} 2=$ water $+1,8 \mathrm{ml}$ kombucha tea that has been fermented for 9 days in morning and afternoon, $\mathrm{P} 3=$ water $+1,8 \mathrm{ml}$ kombucha tea that has been fermented for 12 days in morning and afternoon. Variables measured were wall thickness and lumen diameter of coronary artery. Data were analyzed with ANOVA followed by Duncan test at 95\% confidence level were performed using SPSS version 10,0. The result showed that kombucha tea did not influences the wall thickness and lumen diameter of coronary artery in rats.
\end{abstract}

Key words: Rattus norvegicus, 50\% kombucha tea level, wall thickness, lumen diameter, coronary artery

\begin{abstract}
Abstrak
Tujuan penelitian ini untuk mengetahui pengaruh pemberian teh kombucha kadar 50\% sebagai drinking water dengan variasi waktu fermentasi. Penelitian ini menggunakan Tikus putih (Rattus norvegicus) jantan sebanyak 16 ekor umur 2 bulan, dengan perlakuan Teh kombucha yang difermentasi selama 6, 9 dan 12 hari pada suhu $25^{\circ} \mathrm{C}$ per oral. Penelitian ini menggunakan Rancangan Acak Lengkap dengan 4 perlakuan (selama 28 hari) dan 4 ulangan, yaitu $: \mathrm{P} 0=$ kontrol, tanpa tambahan teh kombucha, $\mathrm{P} 1=$ air minum $+1,8 \mathrm{ml}$ teh kombucha pagi dan sore fermentasi 6 hari, $\mathrm{P} 2=$ air minum $+1,8 \mathrm{ml}$ teh kombucha pagi dan sore fermentasi 9 hari, $\mathrm{P} 3=$ air minum $+1,8 \mathrm{ml}$ teh kombucha pagi dan sore fermentasi 12 hari. Variabel yang diukur adalah kadar kolesterol, HDL dan LDL. Data yang diperoleh dianalisis menggunakan ANOVA yang dilanjutkan dengan Uji Duncan dengan taraf kepercayaan 95\% dengan menggunakan perangkat lunak SPSS 10,0. Hasil penelitian menunjukkan bahwa pemberian teh kombucha tidak mempengaruhi tebal dinding dan diameter lumen arteria koronaria tikus putih (Rattus norvegicus).
\end{abstract}

Kata kunci: Rattus norvegicus, teh kombucha kadar 50\%, tebal dinding, diameter lumen, arteri koronaria

\section{PENDAHULUAN}

Teh kombucha adalah minuman yang murah dan mudah dibuat oleh masyarakat di Indonesia yang memiliki beberapa khasiat bagi tubuh antara lain dapat mempengaruhi tubuh secara menyeluruh dengan menstabilkan metabolisme tubuh. Melalui peningkatan metabolisme, penimbunan lemak di dalam tubuh yang terlalu banyak dapat dihindari. Teh kombucha mengandung senyawa-senyawa kimia yaitu vitamin B (tiamin / B1, riboflavin / B2, niasin / B3, piridoksin / B6, sianokobalanin / B12), vitamin $\mathrm{C}$ dan polifenol. Teh kombucha diduga berperan dalam metabolisme lemak sehingga mempunyai potensi untuk menurunkan kadar kolesterol LDL dan trigliserida, serta meningkatkan kadar HDL, hingga bisa mengurangi risiko terhadap penyakit pembuluh darah dan jantung koroner . Katekin merupakan salah satu unsur dari polifenol dapat mencegah tekanan darah tinggi, mengurangi penimbunan kolesterol dalam darah, mempercepat pembuangan kolesterol melalui feses, menangkal 
radikal bebas, serta dapat mengurangi risiko penyakit kardiovaskuler (Naland, 2008).

Hasil penelitian yang telah dilakukan oleh

Purwaning (2010) dan Rahayu (2005) menggunakan teh kombucha terhadap tikus putih menunjukkan penurunan kadar kolesterol. Hal ini didukung pula oleh Winarni dkk. (2010) yang menyatakan bahwa teh kombucha mempunyai kecenderungan menurunkan kadar kolesterol darah meskipun secara statistik tidak terbukti dengan obyek perlakuan terhadap mahasiswa Fakultas Kedokteran Universitas Sebelas Maret Surakarta. Adriani et al. (2011) yang menggunakan itik sebagai hewan percobaan menyatakan bahwa teh kombucha dapat menurunkan kadar kolesterol total darah, selain itu juga mengurangi kolesterol LDL dan menaikkan kolesterol HDL sesudah mengkonsumsi teh kombucha selama 4 minggu. Hasil penelitian Pratiwi et al. (2012) menyatakan pembuatan teh kombucha mempunyai kandungan alkohol tertinggi pada fermentasi hari ke-12 dan menurun pada hari ke-16, kandungan vitamin $\mathrm{C}$ menurun pada hari ke-4 dan meningkat kembali hingga hari ke-16. Asam total terus meningkat sampai hari ke-16, nilai $\mathrm{pH}$ dan gula total semakin menurun pada hari ke-16.

Kolesterol di dalam darah beredar tidak dalam keadaan bebas, akan tetapi berada dalam partikel - partikel lipoprotein. Lipoprotein merupakan senyawa kompleks antara lemak dan protein. Lipoprotein terdiri atas 4 jenis yaitu kilomikron, VLDL, low density lipoprotein (LDL), dan high density lipoprotein (HDL) (Devlin, 2002; Mayes \& Botham, 2003 $)$. Satu atau lebih apoprotein (protein dan polipeptida) ditemukan pada setiap lipoprotein. Apoprotein utama HDL adalah apoprotein A, apoprotein utama LDL adalah apoprotein B, yang juga ditemukan pada VLDL dan kilomikron. Fungsi apoprotein A sebagai reseptor HDL dan apoprotein B sebagai reseptor LDL. Aterosklerosis berkaitan dengan rasio yang tinggi LDL:HDL atau rasio tinggi apoprotein B:A dalam plasma (Mayes \& Botham, 2003 ${ }^{\mathrm{b}}$ ). Apoprotein B merupakan protein utama dalam partikel lipoprotein aterogenik dan terutama terdapat dalam partikel LDL. Setiap partikel LDL mengandung satu molekul apo B, dengan demikian konsentrasi apoprotein B mencerminkan jumlah partikel LDL dalam tubuh (Haksa, 2010).
Aterosklerosis berhubungan dengan peningkatan LDL. Pengaruh peningkatan kadar LDL akan diikuti akumulasi ester kolesterol dalam makrofag sehingga kemudian makrofag disebut sebagai sel busa. Kadar LDL yang tinggi menyebabkan tingginya kadar LDL intimal. Selanjutnya, LDL intimal akan mengalami oksidasi dan menarik monosit dari sirkulasi darah serta berubah secara fenotipik menjadi makrofag. Peningkatan LDL teroksidasi pada dinding arteri disertai dengan terbentuknya sel busa, akan berkembang menjadi lempeng lemak (Yanuartono, 2007).

Berdasarkan latar belakang di atas, perlu dilakukan penelitian untuk mendapatkan bukti dan informasi tentang tebal dinding dan diameter lumen arteria koronaria tikus putih setelah pemberian teh kombucha kadar $100 \%$ sebagai drinking water dengan variasi waktu fermentasi.

\section{BAHAN DAN METODE}

Penelitian dilakukan di Laboratorium Biologi Struktur dan Fungsi Hewan Departemen Biologi Fakultas Sains dan Matematika Universitas Diponegoro Semarang. Hewan percobaan menggunakan tikus putih (Rattus norvegicus) jantan sebanyak 16 ekor umur 2 bulan, sedang untuk bahan perlakuan yaitu Teh kombucha kadar $50 \%$ yang difermentasi selama 6,9 dan 12 hari pada suhu $25^{\circ} \mathrm{C}$ per oral dengan spuit injeksi ujung berkanul. Adapun alat-alat yang digunakan yaitu 20 kandang individu yang dilengkapi dengan tempat minum dan pakan, gelas ukur, timbangan digital, disetting set.

Penelitian ini menggunakan Rancangan Acak Lengkap dengan 4 perlakuan dan 4 ulangan yaitu : P0 = kontrol, tanpa tambahan teh kombucha, P1 = air minum $+1,8 \mathrm{ml}$ teh kombucha kadar $50 \%$ pagi dan sore fermentasi 6 hari, $\mathrm{P} 2=$ air minum $+1,8 \mathrm{ml}$ teh kombucha kadar $50 \%$ pagi dan sore fermentasi 9 hari, $\mathrm{P} 3=$ air minum $+1,8 \mathrm{ml}$ teh kombucha kadar $50 \%$ pagi dan sore fermentasi 12 hari. Pakan dan minum diberikan secara ad libitum .

Preparat histopatologi arteri koronaria dibuat dengan metode parafin dan fiksatif yang digunakan adalah larutan $10 \%$ neutral buffered formalin. Tahapan yang dilakukan setelah proses fiksasi adalah melakukan pemotongan tipis jaringan setebal kurang lebih $4 \mathrm{~mm}$ dengan orientasi sesuai 
dengan organ yang akan dipotong (trimming). Pisau yang digunakan untuk trimming adalah pisau skalpel No. 22-24. Jumlah potongan jaringan yang dapat dimuat dalam embedding cassette berkisar antara 1-5 buah disesuaikan dengan ukuran organ. Dehidrasi jaringan dilakukan setelah trimming menggunakan tissue processor (Leica, Germany), ini dimaksudkan untuk mengeluarkan air yang terkandung dalam jaringan dengan menggunakan cairan dehidran seperti etanol atau iso propyl alkohol. Cairan dehidran kemudian dibersihkan dari dalam jaringan dengan menggunakan reagen pembersih (clearing agent) yaitu xylol. Reagen pembersih ini akan diganti dengan parafin dengan cara dimasukkan dalam larutan parafin cair sehingga parafin terpenetrasi ke dalam jaringan; proses ini disebut impregnasi. Parafin yang digunakan mempunyai titik cair $56-58^{\circ} \mathrm{C}$.

Variabel yang diukur adalah tebal dinding dan diameter lumen arteri koronaria. Data yang diperoleh dianalisis dengan ANOVA, berdasarkan Rancangan Acak Lengkap (RAL) pada taraf kepercayaan $95 \%(\alpha=0,05)$ (Mattjik dan Sumertajaya, 2006). Analisis keseluruhan menggunakan perangkat lunak software SPSS 10,0

\section{HASIL DAN PEMBAHASAN}

Pengaturan waktu dehidrasi pada tissue processor diberikan pada pada Tabel 1. Setelah melalui proses dehidrasi, jaringan yang berada di dalam embedding cassette dipindahkan ke dalam base mold, kemudian diisi dengan parafin cair dan dilekatkan pada embedding cassette yang disebut blok. Jaringan dalam blok yang telah dingin, selanjutnya dipotong pada ketebalan irisan $4 \mu$ dengan rotary microtome. Irisan tersebut ditempel pada gelas objek yang sebelumnya diolesi Mayer's egg albumin dan ditetesi aquades kemudian dibiarkan kering pada suhu kamar. Untuk selanjutnya setelah preparat mikroanotomi kering dilakukan pewarnaan dengan metode pewarnaan Hematoxylin Ehrlich-Eosin, kemudian dilakukan mounting dengan meneteskan entelan secukupnya dan ditutup dengan coverglass. Pengamatan preparat pada setiap perlakuan dilakukan dengan mikroskop cahaya untuk menentukan tebal dinding dan diameter lumen arteri koroner antar kelompok perlakuan.

Tabel 1. Pengaturan waktu dehidrasi pada tissue processor

\begin{tabular}{lll}
\hline Proses & Cairan & Waktu \\
\hline Dehidrasi & Alkohol 80\% & 2 jam \\
& Alkohol 95\% & 2 jam \\
& Alkohol 95\% & 1 jam \\
& Alkohol absolut & 1 jam \\
& Alkoho absolutl & 1 jam \\
& Alkoho absolut; & 1 jam \\
Clearing & Xylol & 1 jam \\
& Xylol & 1 jam \\
& Xylol & 1 jam \\
Impregnasi & Parafin & 2 jam \\
& Parafin & 2 jam \\
& Parafin & 2 jam \\
\hline
\end{tabular}

Tabel 2. Hasil analisis rata-rata tebal dinding dan diameter lumen arteri koronaria $(\mu \mathrm{m})$ pada pada Tikus putih (Rattus norvegicus) jantan setelah pemberian Teh kombucha kadar 50\% yang difermentasi selama 6, 9 dan 12 hari

\begin{tabular}{lcccc}
\hline Variabel & \multicolumn{2}{c}{ P0 } & P1 & P2 \\
\cline { 2 - 5 } & \multicolumn{4}{c}{$(\mathrm{mg} / \mathrm{dL})$} \\
\hline Tebal dinding & $18.44^{\mathrm{a}} \pm 2.16$ & $18.01^{\mathrm{a}} \pm 1.28$ & $18.25^{\mathrm{a}} \pm 3.00$ & $18.06^{\mathrm{a}} \pm 2.00$ \\
Diameter Lumen & $88.87^{\mathrm{a}} \pm 4.85$ & $85.28^{\mathrm{a}} \pm 6.11$ & $86.12^{\mathrm{a}} \pm 1.3$ & $85.15^{\mathrm{a}} \pm 4.23$ \\
\hline
\end{tabular}

Keterangan : Angka dengan superskrip yang berbeda pada baris yang sama menunjukkan perbedaan yang nyata antar perlakuan pada taraf 95\%. P0 = kontrol, tanpa tambahan teh kombucha kadar 100\%, P1 = air minum $+1,8 \mathrm{ml}$ teh kombucha kadar 50\% pagi dan sore fermentasi 6 hari, P2 = air minum $+1,8 \mathrm{ml}$ teh kombucha kadar $50 \%$ pagi dan sore fermentasi 9 hari, P3 = air minum 1,8 ml teh kombucha kadar 50\% pagi dan sore fermentasi 12 hari. 
Hasil analisis pemberian teh kombucha kadar $50 \%$ yang difermentasi menunjukkan hasil yang tidak berbeda nyata $(\mathrm{P}<0.05)$ baik pada tebal dinding arteri koronaria maupun diameter lumen arteri koronaria. Fermentasi teh kombucha 6,9 dan 12 hari yang diberikan, tidak mempengaruhi tebal dinding dan diameter lumen arteri koronaria pada tikus putih (Rattus norvegicus) pada semua perlakuan seperti tampak pada Tabel 1. Gambar histologis arteria koronaria terlihat jelas struktur pada masing-masing perlakuan yaitu adanya lumen aorta, dinding arteri koronaria, tunika intima, tunika media maupun tunika adventisia seperti terlihat pada Gambar 1, Gambar 2, Gambar 3 dan Gambar 4

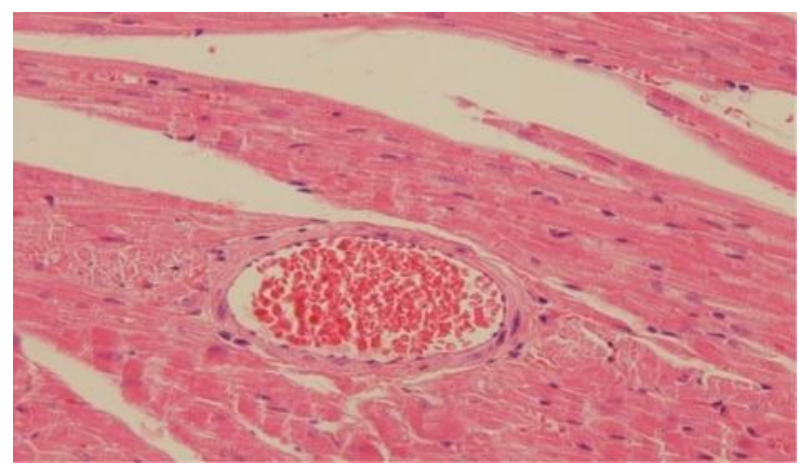

Gambar 1. Arteri koroner tikus putih P0 = kontrol, tanpa tambahan teh kombucha kadar 50\%. A. Lumen arteri koroner dan B. Dinding arteri koroner (H\&E, 40x10)

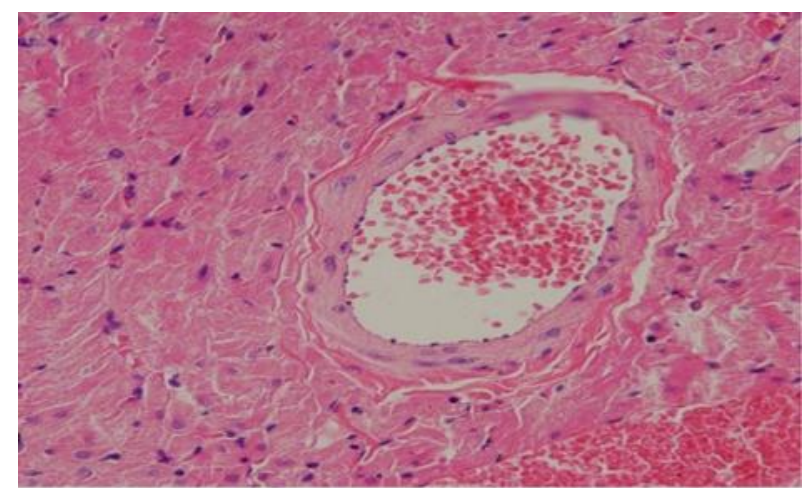

Gambar 2. Arteri koroner tikus putih $\mathrm{P} 1=$ diberi air minum $+1,8 \mathrm{ml}$ teh kombucha kadar $50 \%$ pagi dan sore fermentasi 6 hari. A. Lumen arteri koroner B. Dinding arteri koroner C. Tunika intima D. Tunika media dan E. Tunika adventisia (H\&E, 40x10)

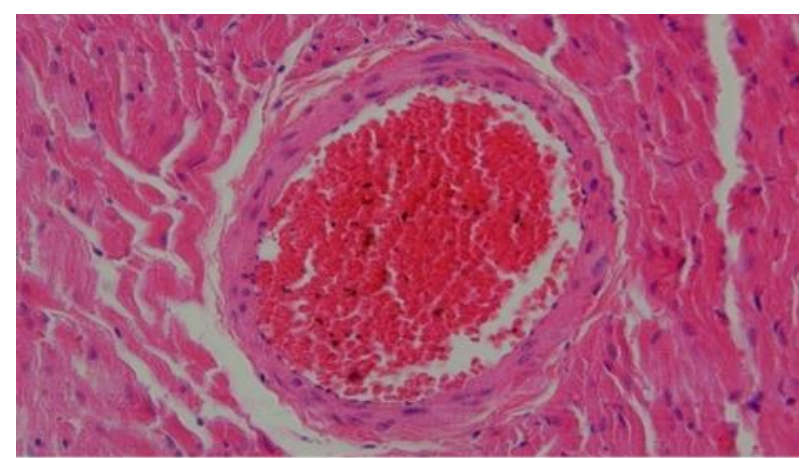

Gambar 3. Arteri koroner tikus putih $\mathrm{P} 2=$ diberi air minum $1,8 \mathrm{ml}$ teh kombucha kadar $50 \%$ pagi dan sore fermentasi 9 hari. A. Lumen arteri koroner dan B. Dinding arteri koroner (H\&E, 40x10)

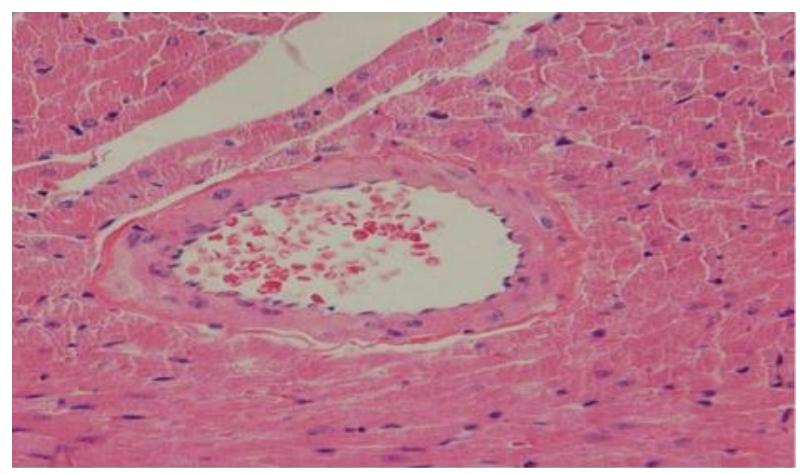

Gambar 4. Arteri koroner tikus putih $\mathrm{P} 3=$ diberi air minum $1,8 \mathrm{ml}$ teh kombucha kadar 50\% pagi dan sore fermentasi 12 hari. A. Lumen arteri koroner B. Dinding arteri koroner C. Tunika intima D. Tunika media dan E. Tunika adventisia (H\&E, 40x10)

Metabolit yang terkandung dalam teh kombucha antara lain adalah niasin atau vitamin (vitamin B3) yang juga disebut asam nikotinat, bekerja di dalam tubuh sebagai koenzim dalam bentuk Nikotinamida Adenin Dinukleotida (NAD) dan Nikotinamida Adenin Dinukleotida Fosfat (NADP). Koenzim ini adalah akseptor hidrogen berikatan dengan atom hidrogen dalam bentuk koenzim dehidrogenase yang merupakan katalis pada reaksi oksidasi reduksi. $\mathrm{NAD}^{+}$berfungsi sebagai koenzim dalam reaksi oksidasi alkohol dalam reaksi berikut : $\mathrm{CH}_{3} \mathrm{CH}_{2} \mathrm{OH}+\mathrm{NAD}^{+} \leftrightarrow$ $\mathrm{CH}_{3} \mathrm{CHO}+\mathrm{NADH}+\mathrm{H}^{+}$. Reaksi ini akan menghasilkan ion $\mathrm{H}^{+}$, maka akan berjalan baik pada 
$\mathrm{pH}$ rendah (suasana asam) (Poedjiadi, 2009). Nikotinamid merupakan komponen dari hampir semua zat-zat pembawa elektron dalam sel hidup (NAD+/NADH; NADP+/NADPH) dan berfungsi dalam banyak lintasan metabolisme terutama dalam: (1) glikolisis anaerob, (2) oksidatif fosforilasi siklus kreb dan (3) sintesis $\beta$-oksidasi asam lemak (Linder, 2010).

Penurunan kadar kolesterol oleh niasin dapat dilakukan dengan cara menghambat perubahan lemak jaringan, mengurangi pengambilan asam lemak bebas oleh hati dan meningkatkan pengeluaran kolesterol oleh hepar melalui getah empedu. Niasin berperan dalam merangsang pembentukan hormon prostaglandin $\mathrm{I}_{2}$ yaitu hormon yang mencegah penggumpaklan (agregasi) trombosit sehingga dapat memperkecil risiko aterosklerosis (Rahayu, 2005).

Hasil penelitian Isdadiyanto (2017) menyatakan bahwa tikus putih yang diberi teh kombucha menunjukkan terjadinya hubungan LDL dengan kolesterol total yang berbanding lurus. Hal tersebut terjadi karena 45\% kolesterol berada dalam bentuk LDL (Mathews \& Van Holde, 2012). Artinya jika kolesterol total turun maka LDL juga turun. Hal ini terjadi karena terhambatnya atau terganggunya proses absorbsi kolesterol di usus halus dan meningkatnya ekskresi asam empedu melalui feses. Asam empedu merupakan hasil metabolisme akhir dari kolesterol. Dengan tingginya ekskresi asam empedu maka akan semakin banyak kolesterol yang diubah menjadi asam empedu untuk mengelmusikan lemak, sehingga kolesterol total dan LDL serum menurun. Lebih lanjut Isdadiyanto (2017) menjelaskan bahwa mekanisme naiknya kadar HDL karena pengaruh pemberian Teh kombucha kemungkinan disebabkan oleh pengikatan asam empedu oleh metabolit (yang terkandung dalam teh kombucha) di dalam usus halus yang menyebabkan meningkatnya ekskresi asam empedu fekal, sehingga terjadi penurunan absorbsi lemak dan kolesterol, hal ini mengakibatkan kolesterol dalam hati rendah sehingga kolesterol untuk memproduksi asam empedu kurang. Kondisi ini merangsang terjadinya sintesis HDL dalam hati untuk memenuhi kekurangan kolesterol tersebut. Akibatnya LDL serum lebih rendah daripada HDL serum.
Salah satu penyakit arteri koroner adalah aterosklerosis. Aterosklerosis terjadi bila arteri koroner tersumbat dan menyempit, sehingga menghambat aliran darah ke otot jantung. Tanpa darah yang mencukupi, jantung akan kekurangan oksigen dan nutrien vital yang dibutuhkan jantung untuk bekerja sebagaimana mestinya. Bila satu pembuluh atau lebih arteri koroner tertutup total, dapat menyebabkan serangan jantung dan akhirnya terjadi kematian (Lewis et al., 2004). Dinding arteri terdiri dari tiga tunika berturut-turut dari bagian dalam ke arah luar yaitu tunika intima, tunika media dan tunika adventisia. Tunika intima terdiri atas satu lapis sel endotelium, tunika media terdiri dari lapisan sel-sel otot polos dan jaringan elastin, tunika adventisia terdiri atas jaringan ikat (Junqueira dan Carneiro, 2003).

Penyakit pada arteria dapat terjadi dengan peningkatan kadar kolesterol LDL dan VLDL dalam darah (hiperkolesterol). Kenaikan kadar kolesterol ini dapat terjadi bila ada gangguan pembentukan kolesterol dalam hepar atau usus halus (Sherwood, 2001). Kadar kolesterol LDL yang tinggi akan memicu penimbunan kolesterol di sel pembuluh darah, yang menyebabkan munculnya aterosklerosis dan terbentuknya plak di dinding pembuluh darah (Libby \& Theroux, 2005). Aterosklerosis berhubungan dengan peningkatan LDL. Pengaruh peningkatan kadar LDL akan diikuti akumulasi ester kolesterol dalam makrofag sehingga kemudian makrofag disebut sebagai sel busa. Kadar LDL yang tinggi menyebabkan tingginya kadar LDL intimal. Selanjutnya LDL intimal akan mengalami oksidasi dan menarik monosit dari sirkulasi darah serta berubah secara fenotipik menjadi makrofag. Peningkatan LDL teroksidasi pada dinding arteri disertai dengan terbentuknya sel busa, akan berkembang menjadi lempeng lemak (Yanuartono, 2007).

Pemberian teh kombucha tidak menyebabkan terbentuknya plak pada dinding arteri koronaria hal ini dibuktikan dengan hasil analisis yang tidak berbeda pada diameter lumen arteria koronaria seperti terlihat pada Tabel 1, bahkan diduga dapat mencegah terbentuknya plak yang akan terbentuk pada arteria koronaria. Hal ini dapat dijelaskan menurut Rahayu (2005) bahwa kandungan teh kombucha mengandung niasin yang berperan dalam merangsang pembentukan hormon 
prostaglandin $\mathrm{I}_{2}$ yaitu hormon yang mencegah penggumpalan (agregasi) trombosit sehingga dapat memperkecil risiko aterosklerosis.

\section{KESIMPULAN}

Teh kombucha kadar 50\% yang difermentasi selama 6, 9 dan 12 hari berpotensi digunakan sebagai suplemen untuk pencegahan risiko terhadap penyakit pembuluh darah dan jantung koroner.

\section{DAFTAR PUSTAKA}

Adriani, L., Mayasari, N., Angga and Kartasudjana, R. 2011. The effect of fermented Kombucha tea on HDL,LDL and Total Cholesterol levels in the duck bloods. Faculty of Animal Husbandry, Padjadjaran University, Bandung. Indonesia. Biotechnology in Animal Husbandry, Volume 27, No. 4. 17491755. 1 maret 2012.

Devlin, M. 2002. Textbook of Biochemistry, with Clinical Corelations. Willeyliss. New York.

Haksa, K. 2010. Kadar kolesterol normal bukan jaminan terbebas dari risiko penyakit jantung koroner. 17 September 2010. Kompas.com. All rights reserved.

Isdadiyanto,S. 2017. Profil lipid tikus putih setelah pemberian teh kombucha kadar $50 \%$ waktu

fermentasi 6, 9 dan 12 hari. Buletin Anatomi dan Fisiologi. Vol. 2. No.1: 80-85.

Junquiera LC, Carneiro J. 2003. Basic Histology: Text \& Atlas. 10 Edition. London. The McGraw-Hill Companies. Inc. Pp. 203-218.

Lewis R, Gaffin D, Hoefnagels M, Parker B. 2004. Life fifth edition. London. McGraw Hill Book Company. Inc.699-703.

Libby, P. and P. Theroux. 2005. Pathophysiology of coronary artery disease. Circulation. 111:3481-3488.

Linder, M.C. 2010. Biokimia Nutrisi dan Metabolisme, dengan Pemakaian secara klinis. Penerjemah Aminuddin Parakkasi. Cetakan ke 1. Penerbit Universitas Indonesia (UI-Press). Jakarta.

Mathews, K.C. and K. E. Van Holde. 2012. Biochemistry. The Benjamin/Cummings Co.Inc. New York.
Mattjik, A.A. dan I.M. Sumertajaya. 2006. Perancangan Percobaan dengan Aplikasi SAS

dan Minitab. Ed. Ke-3. IPB-Press. Bogor.

Mayes, P.A. and K.M. Botham. 2003 a Lipid Storage \& Transport. Harper's Illustrated Biochemistry, $26^{\text {nd }}$ edition. Mc.Graw Hill, 205-217.

Mayes, P.A. and K.M. Botham. 2003 ${ }^{\mathrm{b}}$. Cholesterol Synthesis, Transport, and Excretion. Harper's Illustrated Biochemistry, $26^{\text {nd }}$ edition. Mc.Graw Hill, 219-227.

Naland, H. 2008. Kombucha; Teh dengan seribu khasiat. Agromedia Pustaka, Jakarta.

Poedjiadi, A. 2009. Dasar-dasar Biokimia. UI Press. Jakarta.

Pratiwi, A. Elfira, Aryawati, R. 2012. Pengaruh Waktu Fermentasi terhadap sifat fisik dan kimia pada pembuatan minuman kombucha dari Rumput Laut Sargassum sp. Maspari Journal. 2012. 4(1). 131-136.

Purwaning, A. 2010. Pengaruh kombucha Teh (Acetobacter xylinum) terhadap kadar kolesterol tikus putih jantan (Rattus norvegicus). Jurnal Department of Biology Universitas Muhammadiyah, Malang. Studentresearch.umn.ac.id/print/student_research _4178.html 4 Maret 2012

Rahayu, T. 2005. Kadar kolesterol darah tikus putih setelah pemberian cairan kombucha per oral. Jurusan Pendidikan Biologi, FKIP Universitas Muhammadiyah, Surakarta. Jurnal Penelitian Sains dan Teknologi, Volume 6, No.2.

Sherwood, L. 2001. Human Phisiology: From Cells to Systems. A Division of Internasional Thomson Publishing Inc. All Right Reserved.

Winarni, D., Eva,N., Faqihuddin, A., Galih,H. dan Toumi, S. 2010. Pengaruh pemberian teh kombucha terhadap penurunan kadar kolesterol total dalam darah. Universitas Sebelas Maret Surakarta. Fk.uns.ac.id. 1 Maret 2012

Yanuartono. 2007. Role of high cholesterol and high fat diet on lipid profiles in Sprague Dawley rats. Jurnal Sain Vet. 25: 25-33. 
Pengaruh Fermentasi The Kombucha 